\title{
Targeted temperature management in traumatic brain injury
}

\author{
Shoji Yokobori and Hiroyuki Yokota
}

\begin{abstract}
Traumatic brain injury (TBI) is recognized as the significant cause of mortality and morbidity in the world. To reduce unfavorable outcome in TBI patients, many researches have made much efforts for the innovation of TBI treatment. With the results from several basic and clinical studies, targeted temperature management (TTM) including therapeutic hypothermia $(\mathrm{TH})$ have been recognized as the candidate of neuroprotective treatment. However, their evidences are not yet proven in larger randomized controlled trials (RCTs). The main aim of this review is thus to clarify specific pathophysiology which TTM will be effective in TBI.

Historically, there were several clinical trials which compare TH and normothermia. Recently, two RCTs were able to demonstrate the significant beneficial effects of TTM in one specific pathology, patients with mass evacuated lesions. These suggested that TTM might be effective especially for the ischemic-reperfusional pathophysiology of TBI, like as acute subdural hematoma which needs to be evacuated. Also, the latest preliminary report of European multicenter trial suggested the promising efficacy of reduction of intracranial pressure in TBI.

Conclusively, TTM is still in the center of neuroprotective treatments in TBI. This therapy is expected to mitigate ischemic and reperfusional pathophysiology and to reduce intracranial pressure in TBI. Further results from ongoing clinical RCTs are waited.
\end{abstract}

Keywords: Targeted temperature management, Therapeutic hypothermia, Traumatic brain injury, Ischemia, Reperfusion, Intracranial pressure

\section{Introduction}

In the USA, an estimated 1.4 million people still suffer a traumatic brain injury (TBI) each year [1]. About 50,000 people die before the hospital, and at least 5.3 million live with severe disabilities related to TBI [2]. TBI thus has been a significant and growing public health issue.

The most important factor which determines the prognosis of TBI patients is the severity of the primary brain injury [3]. Additional delayed secondary brain damage is set in progress and continues from the time of traumatic impact in TBI patients, and the two combine to determine outcome [4].

Primary brain injury itself is mostly not amenable to treatment; consequently, the strategy of primary TBI treatment should be prevention, such as use of helmets and vehicle modification. Therefore, the main stream of treatment strategy for TBI should be the surgical

\footnotetext{
* Correspondence: shoji@nms.ac.jp

Department of Emergency and Critical Care Medicine, Nippon Medical School, 1-1-5, Sendagi, Bunkyo-Ku, Tokyo 113-8603, Japan
}

management of TBI and neurointensive care to prevent additional secondary brain injury.

To mitigate the secondary brain injury in TBI patients, many basic and clinical researches have been performed for the innovation of pharmacological treatments and temperature managements [3,5-7].

With the results of numerous previous basic research and clinical trials, targeted temperature management (TTM) including therapeutic hypothermia (TH) has been recognized as the candidate of neuroprotective treatment in the neurocritical care $[8,9]$. However, their clear evidences in TBI patients are not yet proven in large randomized controlled trials (RCTs). TTM for TBI is thus still limited to an optional recommendation (level 3 in Brain Trauma Foundation guideline) [10].

The main aim of this review is to clarify specific pathophysiology for which TTM will be most effective. First, we will mention the general classification of pathophysiology in TBI, and we then will discuss the specific pathophysiology which will be most beneficial with 
TTM. In the latter part of this review, we will focus on the appropriate timing, length, and the rewarming rate of TTM in TBI patients.

\section{Review \\ Definition of "Targeted temperature management" and "Therapeutic hypothermia"}

To maintain normal physiology and to cure pathophysiology in critically ill patients, control of systematic body temperature has been enlightened in neurocritical care settings. However, several terms and definitions surrounding therapeutic body temperature management have also been existed, like TTM, TH, and therapeutic normothermia. In a review of Polderman, "hypothermia" was proposed to be defined as the status of patients' core temperature $<36.0{ }^{\circ} \mathrm{C}$ regardless of the cause. Also, "induced hypothermia" was defined as "intentional reduction of a patients' core temperature below $36.0{ }^{\circ} \mathrm{C}$ ". Further, TH was defined as "Controlled induced hypothermia with the potentially deleterious effects such as shivering, being controlled or suppressed" [5]. On the other hand, TTM is widely including the concept of TH and therapeutic normothermia therapy. A recent report recommends that the term "Targeted temperature management" should replace "therapeutic hypothermia" [11]. In this report which was published from professional societies including the Society of Critical Care Medicine, the term "therapeutic hypothermia" was discarded in favor of TTM with emphasizing the importance of defining a complete temperature profile [11]. According to this recommendation, we also generally define and use the term "TTM" which means temperature management therapy including both of $\mathrm{TH}$ and therapeutic normothermia therapy in this review.

\section{Pathophysiology of TBI}

As mentioned above, the pathophysiology of TBI is mainly divided as primary and secondary brain injuries [12]. Both primary and secondary brain injuries can be further classified by focal or diffuse mechanisms (Table 1). The distinction of focal and diffuse injuries is historically derived from the absence or presence of radiographic mass lesions on computed tomography
[13]. This distinction has now evolved to consider the pathological mechanisms imparted by the trauma in regions local to and remote from the point of impact. Although these classifications are widely accepted, most TBIs consist of a heterogeneous admixture of focal and diffuse damage [12]. Focal and diffuse pathological processes are often intermingled, making it difficult to divide into focal, diffuse, and primary and secondary categories; it is useful to consider them separately for the purpose of understanding the pathophysiology (Table 1).

For example, acute subdural hematoma (ASDH) is a good representative of focal brain injury which also has the aspect of both of primary and secondary brain injuries. In ASDH, neuropathologic study showed ischemic brain damage in the hemisphere underlying the hematoma [14]. An important factor leading to this ischemic damage is raised intracranial pressure (ICP) producing impaired cerebral perfusion. Increasing ICP reduces the volume of cerebral blood circulation. Removal of the hemorrhage may result in the immediate reversal of global ischemia. And this abrupt reduction of mass lesion sometimes induces secondary "reperfusion injury" [14-16]. Previous experimental and clinical studies thus have shown that subdural hematoma and its removal was considered as an ischemic/reperfusion (I/R) pathophysiology in TBI $[17,18]$.

\section{History and future direction of TTM for TBI}

Historically, TTM were induced prior to surgery to assist procedures that caused prolonged ischemia, including open heart surgery $[19,20]$ and various organ transplants [21]. Within its first decade, hypothermia was applied to multiple emergency situations that were characterized by ischemia such as stroke [22, 23], myocardial infarction [24], and cardiac arrest [25, 26].

As we mentioned previously, basic and clinical studies relating the effectiveness of TTM on the neuroprotective effect was also reported in TBI patients [27-29]. In 2001, a larger multicenter trial of hypothermia for neuroprotection in TBI was reported [30] (Table 2). In this RCT, 392 patients with acute brain injury were randomized to normothermia or surface cooling-induced hypothermia. Contrary to the previous phase 2 trial [27],

Table 1 Type and pathophysiology of traumatic brain injury

\begin{tabular}{|c|c|c|}
\hline & Diffuse brain injury & Focal brain injury \\
\hline Primary brain injury & $\begin{array}{l}\text { - Diffuse axonal injury } \\
\text { - Petechial white matter hemorrhage with diffuse vascular injury }\end{array}$ & $\begin{array}{l}\text { - Focal cortical contusion } \\
\text { - Intracerebral hemorrhage } \\
\text { - Extracerebral hemorrhage (i.e., ASDH, AEDH) }\end{array}$ \\
\hline Secondary brain injury & $\begin{array}{l}\text { - Delayed neuronal injury } \\
\text { - Diffuse brain swelling } \\
\text { - Diffuse ischemic injury } \\
\text { - Diffuse hypoxic injury } \\
\text { - Diffuse metabolic dysfunction }\end{array}$ & $\begin{array}{l}\text { - Delayed neuronal injury } \\
\text { - Focal brain swelling } \\
\text { - Focal ischemic injury } \\
\text { - Focal hypoxic injury } \\
\text { - Regional metabolic dysfunction }\end{array}$ \\
\hline
\end{tabular}


Table 2 Recent randomized clinical trials (RCTs) relating TTM on TBI

\begin{tabular}{|c|c|c|c|c|c|c|c|c|c|}
\hline RCTs & $\begin{array}{l}\text { Age } \\
\text { (years old) }\end{array}$ & $\begin{array}{l}\text { No. of } \\
\text { patients }\end{array}$ & Type of TBI & Control temperature & $\begin{array}{l}\text { Time interval of } \\
\text { temperature control }\end{array}$ & $\begin{array}{l}\text { Rewarming } \\
\text { speed }\end{array}$ & Neurologic outcome & Mortality & Comments/references \\
\hline \multirow[t]{2}{*}{ NABIS:H } & \multirow[t]{2}{*}{$16-65$} & \multirow[t]{2}{*}{392} & \multirow[t]{2}{*}{ All, severe } & \multirow[t]{2}{*}{$33^{\circ} \mathrm{C}$ vs $37^{\circ} \mathrm{C}$} & \multirow[t]{2}{*}{$48 \mathrm{~h}$} & \multirow[t]{2}{*}{$0.5^{\circ} \mathrm{C} / 2 \mathrm{~h}$} & \multirow{2}{*}{$\begin{array}{l}57 \% \text { poor outcome in } \\
\text { each group, NS }\end{array}$} & \multirow{2}{*}{$\begin{array}{l}28 \% \text { TH vs } 27 \% \\
\text { Normo, NS }\end{array}$} & Clifton et al. [30] \\
\hline & & & & & & & & & $\begin{array}{l}\text { Weak evidence of improved } \\
\text { outcomes in patients who } \\
\text { were initially hypothermic } \\
\text { on admission }\end{array}$ \\
\hline \multirow[t]{2}{*}{ NABIS:H II } & \multirow[t]{2}{*}{$16-45$} & \multirow[t]{2}{*}{97} & \multirow{2}{*}{$\begin{array}{l}\text { All, severe, } 2.5 \mathrm{~h} \text { after } \\
\text { suffering TBl }\end{array}$} & \multirow{2}{*}{$33^{\circ} \mathrm{C}$ vs $37^{\circ} \mathrm{C}$} & \multirow[t]{2}{*}{$48 \mathrm{~h}$} & \multirow[t]{2}{*}{$0.5^{\circ} \mathrm{C} / 2 \mathrm{~h}$} & \multirow{2}{*}{$\begin{array}{l}60 \text { \% TH } 57 \text { \% Normo, } \\
\text { NS }\end{array}$} & \multirow{2}{*}{$\begin{array}{l}23 \% \text { TH vs } 18 \% \\
\text { Normo NS }\end{array}$} & Clifton et al. [30] \\
\hline & & & & & & & & & $\begin{array}{l}\text { Early-induced hypothermia } \\
\text { proved significantly } \\
\text { efficacious for surgically } \\
\text { evacuated hematoma }\end{array}$ \\
\hline \multirow[t]{2}{*}{ B-HYPO } & \multirow[t]{2}{*}{$15-70$} & \multirow[t]{2}{*}{148} & \multirow[t]{2}{*}{ All } & \multirow[t]{2}{*}{$32-34^{\circ} \mathrm{C}$ vs $35.5-37^{\circ} \mathrm{C}$} & \multirow[t]{2}{*}{$>72 \mathrm{~h}$ and } & \multirow[t]{2}{*}{$<1^{\circ} \mathrm{C} /$ day } & \multirow{2}{*}{$\begin{array}{l}\text { Relative risk (RR) 1.24, } \\
95 \% \text { confidence } \\
\text { interval (Cl) } 0.62-2.48 \text {, } \\
p=0.597, \mathrm{NS}\end{array}$} & \multirow{2}{*}{$\begin{array}{l}\text { (RR 1.82, } 95 \% \mathrm{Cl} \\
0.82-4.03, p= \\
0.180) \text { NS }\end{array}$} & Maekawa et al. [33] \\
\hline & & & & & & & & & $\begin{array}{l}\text { Clinical Trial gov. } \\
\text { NCT00134472 UMIN } \\
000000231\end{array}$ \\
\hline $\begin{array}{l}\text { EUROTHERM } \\
3235\end{array}$ & -65 & 1800 & $\begin{array}{l}\text { Primary closed TBI } \\
\text { with raised ICP } \\
>20 \mathrm{mmHg}\end{array}$ & $32-35^{\circ} \mathrm{C}$ vs Normo & $\begin{array}{l}48 \mathrm{~h} \text { continued for as } \\
\text { long as is necessary } \\
\text { to reduce and maintain } \\
\mathrm{ICP}<20 \mathrm{mmHg}\end{array}$ & NM & - & - & Andrews et al. [89] \\
\hline \multirow[t]{2}{*}{ LTH-1 } & \multirow[t]{2}{*}{$18-65$} & \multirow[t]{2}{*}{300} & \multirow[t]{2}{*}{ All, GCS4-8 } & \multirow{2}{*}{$\begin{array}{l}\text { Longer } \mathrm{TH}\left(34-35^{\circ} \mathrm{C}\right) \text { for } \\
5 \text { days vs Normo }(36- \\
\left.37^{\circ} \mathrm{C}\right)\end{array}$} & \multirow[t]{2}{*}{5 days } & \multirow[t]{2}{*}{$<0.5^{\circ} \mathrm{C} / 4 \mathrm{~h}$} & \multirow[t]{2}{*}{-} & \multirow[t]{2}{*}{-} & Lei et al. [62] \\
\hline & & & & & & & & & $\begin{array}{l}\text { ClinicalTrials.gov Identifier: } \\
\text { NCT01886222 }\end{array}$ \\
\hline HOPES & $21-65$ & 120 & $\begin{array}{l}\text { ASDH with } \\
\text { Evacuated (GCSM } \\
<6)\end{array}$ & $\begin{array}{l}33^{\circ} \mathrm{C} \text { vs } 37^{\circ} \mathrm{C} \\
\text { Preoperative induction }\end{array}$ & $48 \mathrm{~h}$ & $0.1^{\circ} \mathrm{C} / \mathrm{h}$ & - & - & $\begin{array}{l}\text { ClinicalTrials.gov } \\
\text { NCT02064959 and UMIN } \\
000014863\end{array}$ \\
\hline
\end{tabular}

TBI traumatic brain injury, TH therapeutic hypothermia, NS not significant, Normo normothermia, NM not mentioned 
this study could not prove the efficacy of hypothermia in TBI. However, there was a weak evidence of improved outcomes in patients who were initially hypothermic on admission and treated with continued hypothermia for $24 \mathrm{~h}$ [30]. This same study group then tried to confirm the efficacy of very early hypothermia in patients with severe brain injury, the National Acute Brain Injury Study:Hypothermia II (NABIS:H II) [31]. In this NABIS:H II, the early-induced hypothermia did not have efficacy when mortality and morbidity data were looked at. On the other hand, in a sub-populational analysis dividing the patients into those with diffuse brain injury and those with surgical hematoma evacuation, early-induced hypothermia proved significantly efficacious for the latter group [31]. Authors concluded that one explanation was the different pathophysiology between diffuse brain injury and hematoma. These results suggested the efficacy of TTM especially in focal brain injury which received hematoma evacuation and which had the I/R pathophysiology.

The efficacy of early-induced therapeutic hypothermia was also proved in animal experimental TBI model. With considering the data of NABIS:H II, we also hypothesized that preoperatively early induced hypothermia maybe beneficial to mitigate reperfusional injury occurred by craniotomy and clot removal in ASDH rat model [32]. Our data suggested that early, preoperatively induced hypothermia could mediate the reduction of neuronal and glial damage in the reperfusion phase of I/R TBI [32].

More recently, Maekawa et al. compared prolonged mild $\mathrm{TH}$ versus fever control with tight hemodynamic monitoring and slow rewarming in patients with severe traumatic brain injury with a multicenter RCT (B-HYPO) in patients with severe TBI [33] (Table 2). Patients were assigned to either therapeutic hypothermia $\left(32-34{ }^{\circ} \mathrm{C}\right)$ or fever control $\left(35.5-37{ }^{\circ} \mathrm{C}\right)$. Patients with therapeutic hypothermia were cooled as soon as possible for $\geq 72 \mathrm{~h}$ and rewarmed at a rate of $<1{ }^{\circ} \mathrm{C} /$ day. There were no significant differences in the likelihood of poor neurological outcome or mortality between the two groups. However, one subanalysis of this study showed the efficacy of hypothermia especially for young TBI patients who had focal hematoma which needed evacuation [34].

Conclusively, large RCTs still have not yet shown the efficacy of TTM in TBI treatment (Table 2). However, subanalysis of RCTs and animal experimental research showed that early, preoperatively induced hypothermia may mediate the reduction of neuronal and glial damage in the reperfusion phase of focal brain injury which has I/R pathophysiology [4].

Now, an international multicenter RCT (HOPES Trial) is currently in progress. In this trial, nine Japanese centers and three centers in the USA are included as participants. The objective of this trial is to test whether hypothermia improves the outcome following TBI with ASDH requiring evacuation. The primary objective is to determine if rapid induction of hypothermia prior to emergent craniotomy for ASDH will improve the outcome as measured by Glasgow Outcome Scale-Extended (GOSE) at 6 months. Over 120 ASDH patients will be registered by 2018 (ClinicalTrials.gov NCT02064959 and UMIN 000014863).

\section{The mechanisms of I/R brain injury and hypothermia treatment}

Despite much research, the exact mechanisms of the I/R injury itself remain unclear. Reperfusion following ischemia can cause neurovascular injury leading to detrimental changes in the blood-brain barrier (BBB) permeability, cerebral edema, brain hemorrhage, and neuronal death by apoptosis/necrosis [35]. These complications clearly limit the benefits of reperfusional therapies. The processes leading to cellular damage after $I / R$ injury are complex and multifactorial. At this point, the pathology of $I / R$ injury has been separated into two distinct mechanisms. One is the cell death following cellular dysfunction, i.e., excitotoxicity, acidotoxicity, and ionic imbalance. This first process is seen primarily in the ischemic phase. The other type of injury comes from free radical production, and this becomes particularly bad during the reperfusion phase [36]. Together, these mechanisms create a complicated picture of injury (Fig. 1). In the ischemic phase, brain ischemia initiates a cascade of destructive and often irreversible processes that destroy brain cells and tissue. One example of this is the intracellular conversion to anaerobic metabolism [37]. Depletion of adenosine triphosphate (ATP) in the absence of oxidative metabolism leads to failure of the $\mathrm{Na}^{+} / \mathrm{K}^{+}$ATPase pump. This causes depolarization of the cell membrane leading to activation of voltage-gated calcium channels and an influx of intracellular calcium [38]. Moreover, with the anaerobic metabolism induced, intracellular and extracellular acidosis contributes to the calcium influx. This rapid increase in intracellular calcium causes release of large amounts of the excitatory neurotransmitter glutamate, which further stimulates calcium influx in postsynaptic cells [39]. In addition to the above, calcium triggers activation of phospholipase, nitric oxide synthase, proteases, endonucleases, and oxidase enzymes [40]. These activated molecules can easily damage other cell proteins and lipid membranes causing necrosis [41]. Furthermore, recent studies have demonstrated the production of superoxide radicals by $N$-methyl-D-aspartate (NMDA) receptormediated nicotinamide adenine dinucleotide phosphate (NADPH) oxidase activation [42]. Such events amplify reactive oxygen species (ROS) production, mitochondrial dysfunction, and proapoptotic protein activation. Intracellular calcium accumulation itself also triggers initiation of mitochondrial dysfunction and fragmentation 


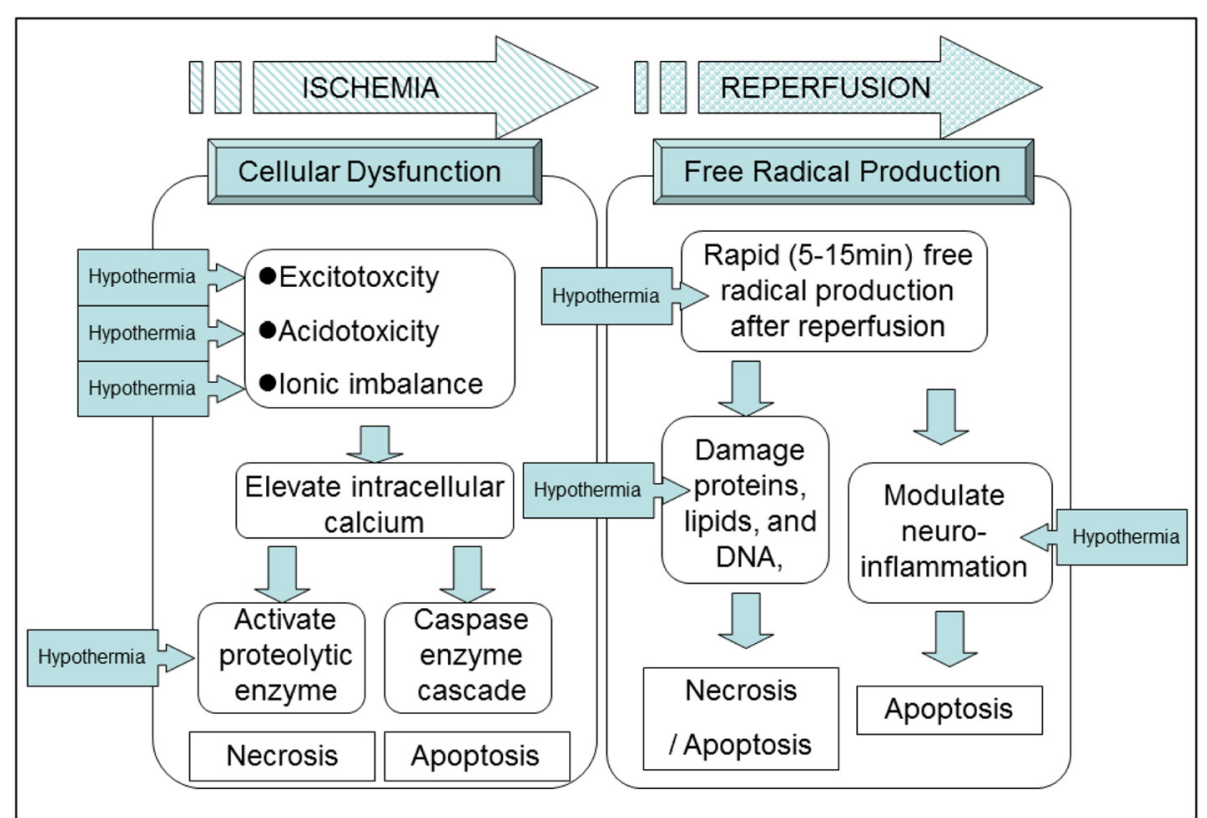

Fig. 1 The schema of mechanisms of ischemic/reperfusional (I/R) brain injury and the effective point of hypothermia treatment. The pathology of I/R injury is approximately separated as two mechanisms, i.e., the cell death following cellular dysfunction in ischemic phase and the free radical production in reperfusion phase. The boxed arrow with entered "Hypothermia" means the estimated effective points in I/R cascade

leading to activation of proapoptotic proteins such as the caspases [43].

Reperfusion to this ischemic tissue results in a short period of excessive free radical production [44]. Experimental measurements of the reperfusion phase demonstrate that oxygen- and carbon-centered free radicals peak within 5 min of reperfusion [45] and that hydroxyl generation peaks within $15 \mathrm{~min}$ [46]. This oxidative stress can damage proteins, lipids, and DNA, possibly leading to necrosis and apoptosis [47, 48]. Oxidants also modulate neuroinflammation [49] leading to increased levels of neuronal apoptosis in adjacent cells [50-52].

Despite much basic and clinical research using hypothermia in I/R brain injury, the mechanisms of its neuronal protection remain unclear. Most believe it to act through a multitude of different pathways. Mitochondrial free radical production might be an important target, and it provides a possible window of opportunity for hypothermia treatment. Supporting this point, hypothermia has been shown to decrease abnormal production of free radicals [53]. Another potential mechanism of hypothermia involves reduction of the inflammatory cascade and cell death pathways of apoptosis and necrosis [54].

Hypothermia also reduces cellular metabolism and oxygen demand while maintaining acceptable ATP levels [55]. Likewise, it improves cellular ion handling and cellular pH balance [37]. In Fig. 1, we illustrate the schema of mechanisms of $I / R$ injury and the estimated points where hypothermia treatment can effect.

\section{How soon is the induction of TTM in order to be} beneficial for brain injury?

The previous studies have shown that hypothermia must be achieved within 2 to $6 \mathrm{~h}$ of severe hypoxic-ischemic injury in animal models. For example, cooling sheep to $34{ }^{\circ} \mathrm{C}$ for $72 \mathrm{~h}$ gave good neuroprotection if started 90 min after the injury. It was partly effective if started at $5.5 \mathrm{~h}$ and was ineffective if started at $8.5 \mathrm{~h}$ [56]. Most clinical trials have suggested that the earlier mild hypothermia is initiated, the more likely beneficial effects may be obtained [30]. Hypothermia is currently being induced by surface cooling with use of cooling blankets, which usually requires 4 to $8 \mathrm{~h}$ to get the target hypothermia temperature $\left(33\right.$ to $\left.35^{\circ} \mathrm{C}\right)$ [30, 57-59].

Bernard et al. reported that cooling can be achieved more rapidly $\left(2{ }^{\circ} \mathrm{C}\right.$ over $30 \mathrm{~min}$ ) by intravenous administration of iced $\left(4^{\circ} \mathrm{C}\right)$ crystalloid solution [59].

Innovation of cooling device also enables rapid induction of TTM in TBI. Recently, the use of intravascular cooling device was spreading in the scene of neurocritical care. This device is now also approved in Japan and widely started to use for TTM in neurocritical care patients. Several reports that compare intravascular cooling to surface cooling exist. de Waard et al. compared the intravascular cooling device and surface cooling device and concluded that time to reach target temperature and cooling speeds was the same between two devices. And the variation coefficient for temperature during maintenance was higher in the surface than that for the 
intravascular cooling group (mean $0.85 \%$ versus $0.35 \%$, $p<0.0001$ ) [60]. This use of cold intravenous fluids and new cooling devices may represent a logical strategy for future clinical trials for accurate TTM in severe TBI.

\section{Therapeutic window for TTM}

There are still no clear evidences on the optimal length of TTM in TBI. A recent experimental research showed that persisting lower temperature significantly reduced the synthesis of hypoxia-inducible factor 1 (HIF-1, a protein relating hypoxic tolerance) under hypoxic conditions and weaken adaptation to hypoxia [61]. On the other hand, a clinical research showed the efficacy of longer hypothermia therapy for neuroprotection in TBI. Jiang et al. performed a single center randomized study to compare the effect of long-term (5 days) mild hypothermia versus short-term (2 days) mild hypothermia suggesting that mild hypothermia may improve the outcome in a series of 215 severe adult TBI patients, when cooling is maintained for longer than $48 \mathrm{~h}$ [57]. More recently, a multicenter RCT to examine the efficacy and safety of long-term mild hypothermia $\left(34-35{ }^{\circ} \mathrm{C}\right.$ for 5 days) in severe TBI is planned in China (the LTH-1 trial) [62].

Rate of rewarming is also an important variable for influencing the protective effects of the hypothermia therapy. In the experimental setting, posttraumatic hypothermia followed by slow rewarming appears to provide maximal protection in terms of traumatically induced axonal damage, microvascular damage and dysfunction, and contusional expansion [63, 64]. In contrast, hypothermia followed by rapid rewarming not only reverses the protective effects associated with hypothermic intervention but also, in many cases, exacerbates the traumatically induced pathology and its functional consequences [64-66].

Conclusively, longer maintenance and slower rewarming may be beneficial in TBI. On the other hand, we also need to be cautious for severe side effects of longer hypothermia maintenance [37].

\section{Preoperative-induced hypothermia for traumatic brain injury}

As we mentioned above, recent clinical studies suggested that preoperatively early induced hypothermia maybe beneficial in focal mass TBI. However, we still cannot find feasibility of pre- and intraoperatively induced hypothermia especially for TBI. There are some reports that used intraoperative hypothermia in neurosurgical procedures involving craniotomy (Table 3) [67-73]. These studies can teach us important lessons in planning future clinical trials using early-induced hypothermia in TBI. Specifically, we have learned that (1) perioperativeinduced hypothermia is feasible and safe and (2) careful consideration should be used in determining the cooling and rewarming durations. All previous hypothermia studies describe no severe complications from the perioperative-induced hypothermia. One should note that their cooling and rewarming durations were all relatively short (Table 3). Important consideration must be given, as several researchers have pointed out, to cooling rate, period of hypothermia, rewarming rate, and volumes of intravenous fluid [74-77].

\section{Induced normothermia and avoiding hyperthermia in TBI:} is it effective?

Clinical studies that prove the efficacy of induced normothermia is much less than that of induced hypothermia. One study from Pittsburgh group showed the efficacy of induced normothermia (fever prophylaxis with intravascular cooling catheter) with reduction of intracranial hypertension compared to control group [78]. More recently, Suehiro et al. reported the Japanese survey of brain temperature management $(\mathrm{TH}$, intensive normothermia, and no temperature management) in patients with traumatic brain injury [79]. In this survey, a total number of 1091 patients were analyzed. Favorable outcome was significantly higher with TH group (52.4\%) compared to intensive normothermia (26.9\%) and no temperature management $(20.7 \%)$. This data suggested that TTM is significantly effective for TBI management comparing to no temperature management.

Several other studies showed that hyperthermia was associated with a statistically significant increase in the increase of ICU stay, lower Glasgow coma scale score on discharge from ICU, and lower neurological function at 6 months after initial injury [80, 81].

Conclusively, appropriate thermoregulation with TTM (TH and intensive normothermia) is significantly important in TBI. Indeed, these data have led to several recommendations for and strict control of temperature in the neuro-ICU settings [82, 83].

\section{TTM for controlling intracranial hypertension in TBI}

Raised ICP and intracranial hypertension are important predictors of mortality in patients with severe TBI [84]. Aggressive treatment of elevated ICP has been shown to reduce mortality and improve outcome [10, 85, 86]. TTM also has been a promising treatment strategy for controlling intracranial pressure in TBI $[87,88]$.

To clarify the effect of TTM for the treatment of intracranial hypertension, the latest clinical trial (EUROTHERM 3235) is now ongoing [89] (Table 2). In this trial, patient with refractory intracranial hypertension (ICP > $20 \mathrm{mmHg}$ ) is assigned as $\mathrm{TH}$ group or control group (standard treatment without any TTM). Two treatment groups are compared with mortality on the 28th day after injury or on discharge. The sample size of this study is estimated as 600 patients. Recently, 
Table 3 Clinical studies using intraoperative hypothermia for neurosurgical procedures

\begin{tabular}{|c|c|c|c|c|c|c|c|c|c|}
\hline Authors and year & No. of cases & $\begin{array}{l}\text { Operative procedure } \\
\text { (number) }\end{array}$ & $\begin{array}{l}\text { Cooling } \\
\text { method }\end{array}$ & Complication & $\begin{array}{l}\text { Mean target } \\
\text { temp }\left({ }^{\circ} \mathrm{C}\right)\end{array}$ & $\begin{array}{l}\text { Mean duration } \\
\text { of hypothermia } \\
\text { (min) }\end{array}$ & $\begin{array}{l}\text { Mean rewarming } \\
\text { rate }\left({ }^{\circ} \mathrm{C} / \mathrm{h}\right)\end{array}$ & $\begin{array}{l}\text { Mean rewarming } \\
\text { temp }\left({ }^{\circ} \mathrm{C}\right)\end{array}$ & $\begin{array}{l}\text { Effectiveness } \\
\text { of hypothermia }\end{array}$ \\
\hline $\begin{array}{l}\text { Baker et al., } \\
\text { [67] } 1994\end{array}$ & $\begin{array}{l}30(\text { Normo } \\
17, \text { Hypo13) }\end{array}$ & $\begin{array}{l}\text { Elective craniotomy for } \\
\text { supratentorial tumor } \\
\text { resection (14), aneurysm } \\
\text { repair (14), other (2) }\end{array}$ & WB & $\begin{array}{l}\text { Shivering (Normo } 0 \\
\text { case vs Hypo } 7 \text { cases, } \\
p=0.002 \text { ). No severe } \\
\text { comp. }\end{array}$ & $34.3 \pm 0.4$ & NR & $0.7 \pm 0.6$ & $35.8 \pm 1.0$ & NR \\
\hline $\begin{array}{l}\text { Clifton and } \\
\text { Christensen, } \\
\text { [68] } 1992\end{array}$ & 21 Hyро & $\begin{array}{l}\text { Aneurysm surgery with } \\
\text { elective craniotomy (21) }\end{array}$ & WB & No comp. & 32.0 & NR & NR & NR & NR \\
\hline $\begin{array}{l}\text { Hindman et al, } \\
\text { [69] } 1999\end{array}$ & $\begin{array}{l}114 \text { (Normo } \\
57, \text { Hypo 57) }\end{array}$ & $\begin{array}{l}\text { SAH clipping (52), } \\
\text { unruptured aneurysm } \\
\text { clipping (62) }\end{array}$ & $A C$ & $\begin{array}{l}\text { No significant difference } \\
\text { between Normo and } \\
\text { Hypo. No severe comp. }\end{array}$ & $\begin{array}{l}33.7(33.2- \\
34.2)\end{array}$ & NR & NR & $35.7(34.9-36.4)$ & NS \\
\hline $\begin{array}{l}\text { Sato and } \\
\text { Yoshimoto [70] } \\
2000\end{array}$ & $\begin{array}{l}60 \text { (Normo } \\
28, \text { Hypo 32) }\end{array}$ & SAH clipping & $A C$ and $W B$ & NR & 34.0 & NR & $\begin{array}{l}\text { Time, } 115 \mathrm{~min} \\
\text { (45-250 min) }\end{array}$ & 36.2 & NR \\
\hline $\begin{array}{l}\text { Steinberg et al., } \\
\text { [71] } 2004\end{array}$ & 153 Нуро & $\begin{array}{l}\text { Elective open craniotomy } \\
\text { for unruptured cerebral } \\
\text { aneurysm }\end{array}$ & $\begin{array}{l}\text { WB(61) vs } \\
\text { endo(92) }\end{array}$ & $\begin{array}{l}\text { Postoperative infection } \\
4.3 \% \text { endo vs } 4.9 \% \\
\text { WB, NS. No severe comp. } \\
\text { in all }\end{array}$ & 33.0 & 274 & $\begin{array}{l}1.88(\mathrm{WB}) \text { vs } 0.69 \\
\text { (endo) }\end{array}$ & $(35-36)$ & $\begin{array}{l}\text { NS between } \\
\text { WB and endo }\end{array}$ \\
\hline $\begin{array}{l}\text { Todd et al, [72] } \\
2005\end{array}$ & $\begin{array}{l}1000 \text { (Normo } \\
501, \text { Hypo 499) }\end{array}$ & SAH clipping & $A C$ & $\begin{array}{l}\text { Postoperative bacteremia } \\
(5 \% \text { Hypo vs } 3 \% \text { Normo, } \\
P=0.05 \text {, no severe comp. } \\
\text { in all. }\end{array}$ & $\begin{array}{l}33.0(32.5- \\
33.5)\end{array}$ & $324 \pm 120$ & NR & $36.4 \pm 1.0$ & NS \\
\hline $\begin{array}{l}\text { Hindman et al., } \\
\text { [73] } 2010\end{array}$ & $\begin{array}{l}441 \text { (Normo } \\
233, \text { Hypo 208) }\end{array}$ & $\begin{array}{l}\text { SAH patients undergoing } \\
\text { temporary clipping }\end{array}$ & $A C$ & NR & $33.3-0.8$ & NR & Time, $120 \mathrm{~min}$ & $36.7-0.5$ & NS \\
\hline
\end{tabular}

Normo normothermia, Hypo hypothermia, SAH subarachnoidal hemorrhage, WB water blanket cooling, AC air cooling, endo endovascular cooling, comp complication, NA, not applicable, NR not reported, NS not significant 
preliminary data of this trial showed the efficacy of TTM with controlling intracranial hypertension [90]. TTM may have a potential as a therapeutic option to control ICP in patients with severe TBI. The final result from this large RCT is waited.

\section{Conclusions}

In this review, first, we explained the classification of TBI pathophysiology. Then, we mentioned the possibility of mild therapeutic hypothermia with focusing on the treatment of I/R-related TBI and intracranial hypertension. With considering previous RCTs, now several multicenter clinical trials including HOPES, EUROTHERM3235, and LTH-1 trial are ongoing. Conclusively, TTM is still in the center of neuroprotective treatments in TBI. These therapies are expected to mitigate ischemic and reperfusional pathophysiology and to reduce intracranial pressure in TBI. Further results from these ongoing clinical RCTs are waited.

\section{Competing interests}

The authors declare that they have no competing interests.

\section{Authors' contributions}

SY searched literatures and drafted the manuscript. HY supervised process of literature search and drafting manuscript. Both authors read and approved the final manuscript.

\section{Acknowledgements}

This work was supported by JSPS Grants-in-aid for Scientific Research Grant Number 26293386 and was supported in part by a research grant from the General Insurance Association of Japan.

Received: 2 July 2015 Accepted: 4 February 2016

Published online: 27 April 2016

\section{References}

1. Binder S, Corrigan JD, Langlois JA. The public health approach to traumatic brain injury: an overview of CDC's research and programs. J Head Trauma Rehabil. 2005:20(3):189-95.

2. Fu ES, Tummala RP. Neuroprotection in brain and spinal cord trauma. Curr Opin Anaesthesiol. 2005;18(2):181-7. doi:10.1097/01.aco.0000162838.56344.88.

3. Yokobori S, Mazzeo AT, Gajavelli S, Bullock MR. Mitochondrial neuroprotection in traumatic brain injury: rationale and therapeutic strategies. CNS Neurol Disord Drug Targets. 2014;13(4):606-19. doi: CNSNDDT-EPUB-57034 [pii].

4. Yokobori S, Frantzen J, Bullock R, Gajavelli S, Burks S, Bramlett H, et al. The use of hypothermia therapy in traumatic ischemic/reperfusional brain injury: review of the literatures. Ther Hypothermia Temp Manag. 2011;1 (4):185-92. doi:10.1089/ther.2011.0012.

5. Polderman KH, Herold I. Therapeutic hypothermia and controlled normothermia in the intensive care unit: practical considerations, side effects, and cooling methods. Crit Care Med. 2009;37(3):1101-20. doi:10. 1097/CCM.0b013e3181962ad5

6. Yokobori S, Mazzeo AT, Hosein K, Gajavelli S, Dietrich WD, Bullock MR. Preconditioning for traumatic brain injury. Transl Stroke Res. 2013;4(1):25-39. doi:10.1007/s12975-012-0226-1.

7. Wright DW, Yeatts SD, Silbergleit R, Palesch YY, Hertzberg VS, Frankel M, et al. Very early administration of progesterone for acute traumatic brain injury. N Engl J Med. 2014:371(26):2457-66. doi:10.1056/NEJMoa1404304.

8. Nielsen N, Wetterslev J, Cronberg T, Erlinge D, Gasche Y, Hassager C, et al. Targeted temperature management at $33^{\circ} \mathrm{C}$ versus $36^{\circ} \mathrm{C}$ after cardiac arrest. N Engl J Med. 2013;369(23):2197-206. doi:10.1056/NEJMoa1310519.
9. Polderman $\mathrm{KH}$, Varon J. Interpreting the results of the targeted temperature management trial in cardiac arrest. Ther Hypothermia Temp Manag. 2015. doi:10.1089/ther.2014.0031

10. Guidelines for the management of severe traumatic brain injury. J Neurotrauma. 2007;24 Suppl 1:S1-106. doi:10.1089/neu.2007.9999.

11. Nunnally ME, Jaeschke R, Bellingan GJ, Lacroix J, Mourvillier B, Rodriguez-Vega GM, et al. Targeted temperature management in critical care: a report and recommendations from five professional societies. Crit Care Med. 2011;39(5): 1113-25. doi:10.1097/CCM.0b013e318206bab2.

12. Gajavelli S, Sinha VK, Mazzeo AT, Spurlock MS, Lee SW, Ahmed Al, et al. Evidence to support mitochondrial neuroprotection, in severe traumatic brain injury. J Bioenerg Biomembr. 2015;47(1-2):133-48. doi:10.1007/s10863-014-9589-1.

13. Saatman KE, Duhaime AC, Bullock R, Maas Al, Valadka A, Manley GT. Classification of traumatic brain injury for targeted therapies. J Neurotrauma. 2008:25(7):719-38. doi:10.1089/neu.2008.0586.

14. Kuroda Y, Bullock R. Local cerebral blood flow mapping before and after removal of acute subdural hematoma in the rat. Neurosurgery. 1992;30(5): $687-91$

15. Miller JD, Bullock R, Graham DI, Chen MH, Teasdale GM. Ischemic brain damage in a model of acute subdural hematoma. Neurosurgery. 1990;27(3):433-9.

16. Burger R, Bendszus M, Vince GH, Solymosi L, Roosen K. Neurophysiological monitoring, magnetic resonance imaging, and histological assays confirm the beneficial effects of moderate hypothermia after epidural focal mass lesion development in rodents. Neurosurgery. 2004;54(3):701-11. discussion 11-2.

17. Kuroda Y, Fujisawa H, Strebel S, Graham DI, Bullock R. Effect of neuroprotective $\mathrm{N}$-methyl-D-aspartate antagonists on increased intracranial pressure: studies in the rat acute subdural hematoma model. Neurosurgery. 1994;35(1):106-12.

18. Yokobori S, Gajavelli S, Mondello S, Mo-Seaney J, Bramlett HM, Dietrich WD, et al. Neuroprotective effect of preoperatively induced mild hypothermia as determined by biomarkers and histopathological estimation in a rat subdural hematoma decompression model. J Neurosurg. 2012. doi:10.3171/ 2012.10.jns 12725.

19. Lewis FJ. Hypothermia in cardiac and general surgery. Minn Med. 1955; 38(2):77-81

20. Swan $\mathrm{H}$. Hypothermia for general and cardiac surgery; with techniques of some open intracardiac procedures under hypothermia. Surg Clin North Am. 1956:1009-24

21. Moossa AR, Zarins CK, Skinner DB. In situ kidney preservation for transplantation with use of profound hypothermia (5 to 20 degrees C.) with an intact circulation. Surgery. 1976;79(1):60-4.

22. Hemmen TM, Raman R, Guluma KZ, Meyer BC, Gomes JA, Cruz-Flores S, et al. Intravenous thrombolysis plus hypothermia for acute treatment of ischemic stroke (ICTUS-L): final results. Stroke. 2010;41(10):2265-70. doi:10. 1161/STROKEAHA.110.592295.

23. De Georgia MA, Krieger DW, Abou Chebl A, Devlin TG, Jauss M, Davis SM, et al. Cooling for acute ischemic brain damage (COOL AID): a feasibility trial of endovascular cooling. Neurology. 2004;63(2):312-7.

24. Dae MW, Gao DW, Sessler DI, Chair K, Stillson CA. Effect of endovascular cooling on myocardial temperature, infarct size, and cardiac output in human-sized pigs. Am J Physiol Heart Circ Physiol. 2002;282(5):H1584-91. doi:10.1152/ajpheart.00980.2001.

25. Abella BS, Zhao D, Alvarado J, Hamann K, Vanden Hoek TL, Becker LB. Intraarrest cooling improves outcomes in a murine cardiac arrest model. Circulation. 2004:109(22):2786-91. doi:10.1161/01.CIR.0000131940.19833.85.

26. Janata A, Holzer M. Hypothermia after cardiac arrest. Prog Cardiovasc Dis. 2009:52(2):168-79. doi:10.1016/j.pcad.2009.07.001.

27. Clifton GL, Allen S, Barrodale P, Plenger P, Berry J, Koch S, et al. A phase II study of moderate hypothermia in severe brain injury. J Neurotrauma. 1993; 10(3):263-71. discussion 73

28. Marion DW, Obrist WD, Carlier PM, Penrod LE, Darby JM. The use of moderate therapeutic hypothermia for patients with severe head injuries: a preliminary report. J Neurosurg. 1993;79(3):354-62. doi:10.3171/jns.1993.79.3.0354.

29. Shiozaki T, Sugimoto H, Taneda M, Yoshida H, Iwai A, Yoshioka T, et al. Effect of mild hypothermia on uncontrollable intracranial hypertension after severe head injury. J Neurosurg. 1993:79(3):363-8. doi:10.3171/ins.1993.79.3.0363.

30. Clifton GL, Miller ER, Choi SC, Levin HS, McCauley S, Smith Jr KR, et al. Lack of effect of induction of hypothermia after acute brain injury. N Engl J Med. 2001;344(8):556-63. doi:10.1056/nejm200102223440803.

31. Clifton GL, Valadka A, Zygun D, Coffey CS, Drever P, Fourwinds S, et al. Very early hypothermia induction in patients with severe brain injury (the 
National Acute Brain Injury Study: Hypothermia II): a randomised trial. Lancet Neurol. 2011;10(2):131-9. doi:10.1016/s1474-4422(10)70300-8.

32. Yokobori S, Gajavelli S, Mondello S, Mo-Seaney J, Bramlett HM, Dietrich WD, et al. Neuroprotective effect of preoperatively induced mild hypothermia as determined by biomarkers and histopathological estimation in a rat subdural hematoma decompression model. J Neurosurg. 2013;1 18(2):370-80. doi:10.3171/2012.10.JNS12725.

33. Maekawa T, Yamashita S, Nagao S, Hayashi N, Ohashi Y. Prolonged mild therapeutic hypothermia versus fever control with tight hemodynamic monitoring and slow rewarming in patients with severe traumatic brain injury: a randomized controlled trial. J Neurotrauma. 2015;32(7):422-9. doi: 10.1089/neu.2013.3197.

34. Suehiro E, Koizumi H, Fujisawa H, Fujita M, Kaneko T, Oda Y, et al. Diverse effects of hypothermia therapy in patients with severe traumatic brain injury based on the computed tomography classification of the traumatic coma data bank. J Neurotrauma. 2015;32(5):353-8. doi:10.1089/neu.2014.3584.

35. Dietrich WD. Morphological manifestations of reperfusion injury in brain. Ann N Y Acad Sci. 1994;723:15-24.

36. Lampe JW, Becker LB. State of the art in therapeutic hypothermia. Annu Rev Med. 2011;62:79-93. doi:10.1146/annurev-med-052009-150512.

37. Polderman KH. Mechanisms of action, physiological effects, and complications of hypothermia. Crit Care Med. 2009;37(7 Suppl):S186-202. doi:10.1097/CCM. Ob013e3181aa5241.

38. Badruddin A, Taqi MA, Abraham MG, Dani D, Zaidat OO. Neurocritical care of a reperfused brain. Curr Neurol Neurosci Rep. 2011;11(1):104-10. doi:10. 1007/s11910-010-0156-9.

39. Simon RP. Acidotoxicity trumps excitotoxicity in ischemic brain. Arch Neurol. 2006;63(10):1368-71. doi:10.1001/archneur.63.10.1368.

40. Wahlgren NG, Ahmed N. Neuroprotection in cerebral ischaemia: facts and fancies - the need for new approaches. Cerebrovasc Dis. 2004;17 Suppl 1: 153-66. doi:10.1159/000074808.

41. Leker RR, Shohami E. Cerebral ischemia and trauma-different etiologies yet similar mechanisms: neuroprotective opportunities. Brain Res Brain Res Rev. 2002;39(1):55-73

42. Brennan AM, Suh SW, Won SJ, Narasimhan P, Kauppinen TM, Lee $H$, et al. NADPH oxidase is the primary source of superoxide induced by NMDA receptor activation. Nat Neurosci. 2009;12(7):857-63. doi:10.1038/ nn.2334.

43. Eldadah BA, Faden Al. Caspase pathways, neuronal apoptosis, and CNS injury. J Neurotrauma. 2000;17(10):811-29.

44. Tuttolomondo A, Di Sciacca R, Di Raimondo D, Arnao V, Renda C, Pinto A, et al. Neuron protection as a therapeutic target in acute ischemic stroke. Curr Top Med Chem. 2009:9(14):1317-34.

45. Bolli R, Jeroudi MO, Patel BS, Aruoma Ol, Halliwell B, Lai EK, et al. Marked reduction of free radical generation and contractile dysfunction by antioxidant therapy begun at the time of reperfusion. Evidence that myocardial "stunning" is a manifestation of reperfusion injury. Circ Res. 1989:65(3):607-22.

46. Khalid MA, Ashraf M. Direct detection of endogenous hydroxyl radical production in cultured adult cardiomyocytes during anoxia and reoxygenation. Is the hydroxyl radical really the most damaging radical species? Circ Res. 1993;72(4):725-36.

47. Halliwell B. Free radicals, antioxidants, and human disease: curiosity, cause, or consequence? Lancet. 1994:344(8924):721-4.

48. Sugawara T, Chan PH. Reactive oxygen radicals and pathogenesis of neuronal death after cerebral ischemia. Antioxid Redox Signal. 2003:5(5): 597-607. doi:10.1089/152308603770310266.

49. Wong $\mathrm{CH}$, Crack PJ. Modulation of neuro-inflammation and vascular response by oxidative stress following cerebral ischemia-reperfusion injury. Curr Med Chem. 2008;15(1):1-14

50. Huang Y, Rabb H, Womer KL. Ischemia-reperfusion and immediate T cell responses. Cell Immunol. 2007;248(1):4-11. doi:10.1016/j.cellimm.2007.03.009.

51. Jung JE, Kim GS, Chen H, Maier CM, Narasimhan P, Song YS, et al. Reperfusion and neurovascular dysfunction in stroke: from basic mechanisms to potential strategies for neuroprotection. Mol Neurobiol. 2010;41(2-3):172-9. doi:10.1007/s12035-010-8102-z.

52. Lv M, Liu Y, Zhang J, Sun L, Liu Z, Zhang S, et al. Roles of inflammation response in microglia cell through Toll-like receptors 2/interleukin-23/ interleukin-17 pathway in cerebral ischemia/reperfusion injury. Neuroscience. 2011;176:162-72. doi:10.1016/j.neuroscience.2010.11.066.

53. Shao ZH, Sharp WW, Wojcik KR, Li CQ, Han M, Chang WT, et al. Therapeutic hypothermia cardioprotection via Akt- and nitric oxide-mediated attenuation of mitochondrial oxidants. Am J Physiol Heart Circ Physiol. 2010 298(6):H2164-73. doi:10.1152/ajpheart.00994.2009.

54. Yang D, Guo S, Zhang T, Li H. Hypothermia attenuates ischemia/ reperfusion-induced endothelial cell apoptosis via alterations in apoptotic pathways and JNK signaling. FEBS Lett. 2009;583(15):2500-6. doi:10.1016/j. febslet.2009.07.006.

55. Erecinska M, Thoresen M, Silver IA. Effects of hypothermia on energy metabolism in Mammalian central nervous system. J Cereb Blood Flow Metab. 2003;23(5):513-30. doi:10.1097/01.WCB.0000066287.21705.21.

56. Gunn AJ. Cerebral hypothermia for prevention of brain injury following perinatal asphyxia. Curr Opin Pediatr. 2000;12(2):111-5.

57. Jiang J, Yu M, Zhu C. Effect of long-term mild hypothermia therapy in patients with severe traumatic brain injury: 1-year follow-up review of 87 cases. J Neurosurg. 2000;93(4):546-9. doi:10.3171/jns.2000.93.4.0546.

58. Schwab S, Schwarz S, Spranger M, Keller E, Bertram M, Hacke W. Moderate hypothermia in the treatment of patients with severe middle cerebral artery infarction. Stroke. 1998:29(12):2461-6.

59. Bernard SA, Buist M. Induced hypothermia in critical care medicine: a review. Crit Care Med. 2003:31(7):2041-51. doi:10.1097/01.CCM.0000069731.18472.61.

60. de Waard MC, Banwarie RP, Jewbali LS, Struijs A, Girbes AR, Groeneveld AB. Intravascular versus surface cooling speed and stability after cardiopulmonary resuscitation. Emerg Med J. 2014. doi:10.1136/emermed-2014-203811.

61. Tanaka T, Wakamatsu T, Daijo H, Oda S, Kai S, Adachi T, et al. Persisting mild hypothermia suppresses hypoxia-inducible factor-1alpha protein synthesis and hypoxia-inducible factor-1-mediated gene expression. Am J Physiol Regul Integr Comp Physiol. 2010;298(3):R661-71. doi:10.1152/ajpregu.00732.2009.

62. Lei J, Gao G, Mao Q, Feng J, Wang L, You W, et al. Rationale, methodology, and implementation of a nationwide multicenter randomized controlled trial of long-term mild hypothermia for severe traumatic brain injury (the LTH-1 trial). Contemp Clin Trials. 2015;40:9-14. doi:10.1016/j.cct.2014.11.008.

63. Matsushita Y, Bramlett HM, Alonso O, Dietrich WD. Posttraumatic hypothermia is neuroprotective in a model of traumatic brain injury complicated by a secondary hypoxic insult. Crit Care Med. 2001;29(11):2060-6.

64. Suehiro E, Ueda Y, Wei EP, Kontos HA, Povlishock JT. Posttraumatic hypothermia followed by slow rewarming protects the cerebral microcirculation. J Neurotrauma. 2003:20(4):381-90. doi:10.1089/089771503765172336.

65. Hayashi N. Management of pitfalls for the successful clinical use of hypothermia treatment. J Neurotrauma. 2009;26(3):445-53. doi:10.1089/ neu.2008.0648.

66. Povlishock JT, Wei EP. Posthypothermic rewarming considerations following traumatic brain injury. J Neurotrauma. 2009;26(3):333-40. doi:10.1089/neu. 2008.0604.

67. Baker KZ, Young WL, Stone JG, Kader A, Baker CJ, Solomon RA. Deliberate mild intraoperative hypothermia for craniotomy. Anesthesiology. 1994:81(2):361-7.

68. Clifton GL, Christensen ML. Use of moderate hypothermia during elective craniotomy. Tex Med. 1992;88(12):66-9.

69. Hindman BJ, Todd MM, Gelb AW, Loftus CM, Craen RA, Schubert A, et al. Mild hypothermia as a protective therapy during intracranial aneurysm surgery: a randomized prospective pilot trial. Neurosurgery. 1999;44(1):23-32. discussion -3 .

70. Sato K, Yoshimoto T. Systemic and cerebral haemodynamics during craniotomy under mild hypothermia in patients with acute subarachnoid haemorrhage. Acta Neurochir (Wien). 2000;142(9):1013-9. discussion 9-20.

71. Steinberg GK, Ogilvy CS, Shuer LM, Connolly Jr ES, Solomon RA, Lam A, et al. Comparison of endovascular and surface cooling during unruptured cerebral aneurysm repair. Neurosurgery. 2004;55(2):307-14. discussion 14-5.

72. Todd MM, Hindman BJ, Clarke WR, Torner JC. Mild intraoperative hypothermia during surgery for intracranial aneurysm. N Engl J Med. 2005; 352(2):135-45. doi:10.1056/NEJMoa040975.

73. Hindman BJ, Bayman EO, Pfisterer WK, Torner JC, Todd MM. No association between intraoperative hypothermia or supplemental protective drug and neurologic outcomes in patients undergoing temporary clipping during cerebral aneurysm surgery: findings from the Intraoperative Hypothermia for Aneurysm Surgery Trial. Anesthesiology. 2010;112(1):86-101. doi:10.1097/ ALN.0b013e3181c5e28f.

74. Honeybul S, Ho K, Lind C, Gillett G. Hypothermia in patients with brain injury: the way forward? Lancet Neurol. 2011;10(5):405-6. doi:10.1016/S14744422(11)70086-2. author reply 6-7.

75. Nichol AD, Trapani T, Murray L, Vallance S, Cooper DJ. Hypothermia in patients with brain injury: the way forward? Lancet Neurol. 2011;10(5):405. doi:10.1016/S1474-4422(11)70085-0. author reply 6-7. 
76. Polderman $\mathrm{KH}$, Andrews PJ. Hypothermia in patients with brain injury: the way forward? Lancet Neurol. 2011;10(5):404-5. doi:10.1016/S14744422(11)70084-9. author reply 6-7.

77. Takeuchi S, Nawashiro H, Otani N. Hypothermia in patients with brain injury: the way forward? Lancet Neurol. 2011;10(5):404. doi:10.1016/S14744422(11)70083-7. author reply 6-7.

78. Puccio AM, Fischer MR, Jankowitz BT, Yonas H, Darby JM, Okonkwo DO. Induced normothermia attenuates intracranial hypertension and reduces fever burden after severe traumatic brain injury. Neurocrit Care. 2009;11(1): 82-7. doi:10.1007/s12028-009-9213-0.

79. Suehiro E, Koizumi H, Kunitsugu I, Fujisawa H, Suzuki M. Survey of brain temperature management in patients with traumatic brain injury in the Japan neurotrauma data bank. J Neurotrauma. 2014;31(4):315-20. doi:10. 1089/neu.2013.3057.

80. Bao L, Chen D, Ding L, Ling W, Xu F. Fever burden is an independent predictor for prognosis of traumatic brain injury. PLoS One. 2014;9(3): e90956. doi:10.1371/journal.pone.0090956.

81. Natale JE, Joseph JG, Helfaer MA, Shaffner DH. Early hyperthermia after traumatic brain injury in children: risk factors, influence on length of stay, and effect on short-term neurologic status. Crit Care Med. 2000;28(7):2608-15.

82. Kilpatrick MM, Lowry DW, Firlik AD, Yonas H, Marion DW. Hyperthermia in the neurosurgical intensive care unit. Neurosurgery. 2000;47(4):850-5. discussion 5-6.

83. Diringer $\mathrm{MN}$. Treatment of fever in the neurologic intensive care unit with a catheter-based heat exchange system. Crit Care Med. 2004;32(2):559-64. doi: 10.1097/01.CCM.0000108868.97433.3F.

84. Farahvar A, Gerber LM, Chiu YL, Carney N, Hartl R, Ghajar J. Increased mortality in patients with severe traumatic brain injury treated without intracranial pressure monitoring. J Neurosurg. 2012;117(4):729-34. doi:10. 3171/2012.7.JNS111816.

85. Bratton SL, Chestnut RM, Ghajar J, McConnell Hammond FF, Harris OA, Hart $\mathrm{R}$, et al. Guidelines for the management of severe traumatic brain injury. VIII. Intracranial pressure thresholds. J Neurotrauma. 2007;24 Suppl 1:S55-8. doi: 10.1089/neu.2007.9988

86. Onda H, Fuse A, Yamaguchi M, Igarashi Y, Watanabe A, Suzuki G, et al. Traumatic cerebrovascular injury following severe head injury: proper diagnostic timetable and examination methods. Neurol Med Chir (Tokyo). 2013;53(9):573-9.

87. Tokutomi T, Miyagi T, Takeuchi Y, Karukaya T, Katsuki H, Shigemori M. Effect of 35 degrees $C$ hypothermia on intracranial pressure and clinical outcome in patients with severe traumatic brain injury. J Trauma. 2009;66(1):166-73. doi:10.1097/TA.0b013e318157dbec.

88. Tokutomi T, Morimoto K, Miyagi T, Yamaguchi S, Ishikawa K, Shigemori M. Optimal temperature for the management of severe traumatic brain injury: effect of hypothermia on intracranial pressure, systemic and intracranial hemodynamics, and metabolism. Neurosurgery. 2003;52(1):102-11. discussion 11-2.

89. Andrews PJ, Sinclair LH, Harris B, Baldwin MJ, Battison CG, Rhodes JK, et al. Study of therapeutic hypothermia $\left(32\right.$ to $35^{\circ} \mathrm{C}$ ) for intracranial pressure reduction after traumatic brain injury (the Eurotherm3235Trial): outcome of the pilot phase of the trial. Trials. 2013;14:277. doi:10.1186/1745-6215-14-277.

90. Flynn LM, Rhodes J, Andrews PJ. Therapeutic hypothermia reduces intracranial pressure and partial brain oxygen tension in patients with severe traumatic brain injury: preliminary data from the Eurotherm3235 Trial. Ther Hypothermia Temp Manag. 2015. doi:10.1089/ther.2015.0002.

\section{Submit your next manuscript to BioMed Central and we will help you at every step:}

- We accept pre-submission inquiries

- Our selector tool helps you to find the most relevant journal

- We provide round the clock customer support

- Convenient online submission

- Thorough peer review

- Inclusion in PubMed and all major indexing services

- Maximum visibility for your research

Submit your manuscript at www.biomedcentral.com/submit
() BioMed Central 